\title{
Evaluation of Public Accountability and Tax Culture among Tax Payers in Nigeria
}

\author{
Emmanuel Igbo Igbeng ${ }^{1}$, Sunny Biobele Beredugo ${ }^{1 *}$, Vincent Adaka Adu ${ }^{1}$ \\ ${ }^{1}$ Department of Accounting, University of Calabar, Calabar, Cross Rivers State, Nigeria \\ "Email (corresponding author): sunnyisaiah002@gmail.com
}

\begin{abstract}
This study is about public accountability and tax culture in Nigeria. The article specifically evaluates the extent to which government's accountability, transparency and act in the interest of the public create a sustainable tax culture in Nigeria and whether clear definition of responsibility, adherence to reporting mechanism and strict system review and sanctions enhance Nigerian tax culture among others. Survey research design was used and information was gathered from 782 tax payers from Edo, Enugu and Bayelsa States. The study adopted Pearson Product Moment Correlation (PPMC), Ordinary Least Square (OLS) and Multivariate Analysis of Variance (MANOVA) for testing the hypotheses. It was discovered that government's accountability, transparency and act in the interest of the public create a sustainable tax culture in Nigeria; and clear definition of responsibility, adherence to reporting mechanism, and strict system review and sanctions enhance Nigerian tax culture, while unaccountability can lead to diverse consequences such as loss of government popularity among others. It is, therefore, recommended that in order to boast the Nigerian tax culture, government should be accountable, transparent and always act in the best interest of the public.
\end{abstract}

Keywords: Public accountability, Trust, Public interest, Responsibility, Adherence to reporting mechanism, System review and sanctions, Nigerian tax culture

\section{Introduction}

The Nigerian tax system has undergone several reforms, yet, it is still lacking in the unifying theme of achieving high tax compliance. It has been established without prejudice that Nigeria lacks tax culture. This is because Nigeria is grappling with low tax compliance and many people see no reason for tax payment (Achor, 2014). Researchers have accentuated on several variables that might be responsible for tax avoidance and evasion, while the Federal Inland Revenue Services (IFRS) have speculated that it is not difficult to understand why there is no strong tax culture among the Nigerians. It is important to state that tax cultures all over the world are socio-economically and environmentally specific. Citizens can only be symbiotic partners with governments, if they engage in people orientated projects and are able to give stewardship of their economic and other financial engagements which is imperative for the societal advancement.

Presently, Nigerian government is unaccountable of the funds entrusted in their care. Issues concerning what successive governments have done with tax payers' monies still remain unanswered (Appah and Appiah, 2010). As a corollary, the concomitant disparities in the overall budget and the actual (physical) expenditure are quite glaring. Most government officials also engage in self-centered projects and conceal from the public.

It is suffice to say that no meaningful individual would want to make a contribution in terms of tax payment to an unaccountable party. The big question here is if tax payers can be made to pay their taxes voluntarily if governments are accountable to their electorates while engaging in people orientated projects. Can governments' clear definition of responsibility, adherence to reporting mechanism and strict system review and sanctions enhance the Nigerian tax culture? Most tax payers are not complying with the provision of the tax law, because of the high level of moral 
decadence among government officials who aggrandize themselves using revenue from the State and tax payers' monies with impunity, while economic hardship remains the order of the day. However, in the midst of penury and scarcity, tax payers are obliged to pay their tax. In view of this, can government's accountability, transparency and act in the interest of the public create a sustainable tax culture in Nigeria?

In generic term, Nigerian's total revenue is nothing compared to the actual expenditures that might put smiles on the faces of the common man. High rates of poverty, unemployment, dilapidated infrastructure, epileptic power supply, insecurity, high cost of education and health care among others are reflections of corruption in places which bring accountability onto the desk. Governments claim they have spent billions of Naira to salvage these lingering epidemics, yet, Nigerians in most occasions, exhibit their anger through tax evasion. This puts a poser of what happens with a government that is not accountable to its citizenry.

\section{Public accountability and sustainable tax culture in Nigeria}

Stakeholders expect the accruing revenue to expend properly and pragmatically, in a well-thought manner as well as in line with the ideals of strategic management (Agundu and Ogbole, 2014). Government should give stewardship of its affairs (Davies, 1999). Worrisome is that the tax revenues within 2012 and 2014, despite dwindling, show astronomical increase. However, rather than recording a remarkable progress in nation's socio-economic development, Nigeria retrogressed as one of the poorest countries in the world amidst plenty. Tax payers are apprehensive of the need for paying taxes when governments are not accountable. In a similar vein, adequate capacity of facilitating the process of public accountability to improve performance and government commitment to the people are lacking in all ramifications. Lack of public accountability in Nigeria is having a severe blow on its tax culture. International global perception index of transparency ranked Nigeria 134 among 178 countries in 2010; 143 among 178 countries in 2011; 139 among 175 countries in 2012; 144 among 175 countries in 2013; 136 among 175 countries in 2014. Officials, law makers and citizenry need information that confirms whether government funds have been judiciously spent in accordance to regulations (Udo, 2015). According to Alm, Mccelland and Schulze (1992), trust in government affect tax compliance of citizens and increase their tendency to declare taxable revenue more precisely. Government can only be trusted when they are accountable, transparent and act in the interest of the public. Olowu (2002) affirmed that while public interest is crucial to public accountability, transparency is also cardinal to it. Accountability refers to answering for one's action or behavior. In this context, however, public accountability is the process whereby public office holders such as Governors, Ministers, Permanent secretaries and Directors of government owned Ministries, Department and Agencies (MDAs) give account of their stewardship to members of the public.

Okoh and Ohwoyibo (2009) added that public accountability reflect the need for government and its agencies to serve public interest in accordance with the law of the land. Olowu (2002) corroborates that public accountability has three crucial components, namely a clear definition of responsibility, reporting mechanism and a system of review, reward and sanctions. Public accountability implies the rendering of account for public interest (Scott, 2000). Government is held accountable by the public for the way it uses its discretion and spent tax money. Accountability is the price government has to pay for exercising its authority. The principle of democracy in Nigeria requires representative government. Elected officials should represent the will of the people and ensure that government is accountable to its citizenry. However, this is not the case in Nigeria. The rates at which State Governors in Nigeria enrich themselves through external borrowing, the course of which they throw their States in huge debt burden after the completion of their tenures in office is alarming. Investigation shows that there are no checks and balances. State governors borrow without adequate approval from their respective State Houses of Assembly. There is simply financial autonomy. Governors masquerade themselves as demigods that can do whatever they want with tax payers' monies at whim; while the Fiscal Responsibility Commission saddled with the responsibility of evaluating government activities in terms of spending and borrowing is hardly living-up to their expectations. According to Jim-Nwoko (2014), the commission which was empowered through Fiscal Responsibility Act 2007 had to provide for prudent management of the nation's resources, ensure long-term macroeconomic stability of the national economy, secure greater accountability and transparency in Fiscal operations within the medium-term Fiscal Policy Framework and to ensure the promotion and enforcement of the nation's economic objectives and other related matters. The commission had to compel both the Federal and State governments and their institutions to be transparent enough to disclose information relating to public revenues and expenditure; borrowing only when necessary, considering the ability of the nation to pay back, being accountable, transparent and open and encouraging popular participation. 
However, barely three States in the whole Federation have been able to disclose their 2014 Financial Statements in August 2015; it was only a write-up and nothing has been done about it. Most State Governors borrow without adequate scrutiny by their State Houses of Assemblies who instead of being a check to their respective Governors descend to be a puppet. When it is looked critically, the assumption of "he, who pays the piper, detects the tune" was hovering around their activities. This is because the allowances of the Houses of Assemblies are paid by the State Governors and where they fail to approve the Governor's request on loan for instance, even when it is not of the best interest of the masses, the State Executive might return similar gesture in the payment of their allowances on the guise that there is no fund. The Economic and Financial Crimes Commission (EFCC), together with the Independent and Corrupt Practices and Other Offences Commission (ICPC) are still sleeping to the clarion calls of bringing corrupted officials 'to book'. This is because they are selective in their prosecution of corruption-related cases (Abbah, Abubakar, Abdallah, \& Adebayo, 2011). All of these are having a negative impact on tax payers who are either evading tax payment or grudgingly complying.

Tax payers' compliance level is tied to Government's obligation to the society. Government who engages in gross mismanagement of resources, inability of paying salaries should not expect tax payers to oblige to government's requests. They go home with "Jumbo Packages" in the name of security votes and still ask people pay tax? The Nigerian tax culture is a reflection of the agency theory between the principal and the agents. This is because the agent (government) is expected to act in the best interest of the people. At the point, they fail to uphold their own side of the bargain, the principal (tax payers) will become reluctant to further release funds (tax payment). Thus, unfavorable tax culture is shaped by government breach of trust and high level of corruption among its officials. Roth, Scholz and Dryden-Witte (1989) claim that various cultural contexts which shape a person's interpretation of events may assist in influencing his or her attitude toward tax evasion or compliance; the taxpayer's attitude towards tax is an expression of his belief and judgement on the fairness of the system and trust in government. They are simply motivated by the benefit derivable of the system (Bobek, 1997).

Onuba (2013) reported that the Acting Executive Chairman of Federal Inland Revenue Service, Mr. Kabir Mashi, while speaking on the country's tax system affirmed that Nigeria lacks tax culture, and confirmed that a lot of tax payers still feel reluctant to comply with tax laws and they use all sorts of excuses including government's inability to engage in development. He reiterated that the Nigerian citizens should see themselves as partners with government, yet, he failed to advice governments on their obligations to perform and failed to explain publicly, fully and fairly how it affects the public to see government carrying out its responsibilities.

\section{Data and Methodology}

The study engaged a survey research design using questionnaire to generate variables from a cross-session of tax payers in Edo, Enugu and Bayelsa States. It sampled 850 respondents in order to gather information on government's accountability, transparency, public interest and sustainable tax culture in Nigeria. Pearson Product Moment Correlation (PPMC), Ordinary Least Square (OLS) and Multivariate Analysis of Variance (MANOVA) were used to test the hypotheses. The actual engagements with respondents show that 782 copies of questionnaire were returned.

\section{Hypotheses testing}

1. Government's accountability, transparency and act in the interest of the public create a sustainable tax culture in Nigeria;

2. Clear definition of responsibility, adherence to reporting mechanism, and strict system review and sanctions affect Nigerian tax culture;

\section{Analysis and Results}

Table 1 shows the perceptions of tax payers through the correlational result of Government's accountability, transparency and act in the interest of the public on the sustainable tax culture in Nigeria. The result shows that there are high correlations between Government's accountability [rcal $=0.977>\mathrm{t}$ cri $=0.05]$, transparency [rcal $=0.953>\mathrm{t}$ cri $=0.05]$ and act in the interest of the public $[\mathrm{rcal}=0.953>\mathrm{t}$ cri $=0.05]$ on the sustainable tax culture in Nigeria. All of the results are significant at 0.01 levels. 
Table 1: Correlations

\begin{tabular}{|ll|r|r|r|r|}
\hline & & $\begin{array}{c}\text { Government } \\
\text { accountability }\end{array}$ & Transparency & $\begin{array}{c}\text { Public } \\
\text { Interest }\end{array}$ & $\begin{array}{c}\text { Tax } \\
\text { Culture }\end{array}$ \\
\hline Government & Pearson Correlation & 1 & $.929^{* * *}$ & $.941^{* * *}$ & $.977^{* * *}$ \\
accountability & Sig. (2-tailed) & .000 & .000 & .000 \\
& $\mathrm{~N}$ & 782 & 782 & 782 & 782 \\
\hline Transparency & Pearson Correlation & $.929^{* *}$ & 1 & $.951^{* *}$ & $.953^{* *}$ \\
& Sig. (2-tailed) & .000 & & .000 & .000 \\
& $\mathrm{~N}$ & 782 & 782 & 782 & 782 \\
\hline Public Interest & Pearson Correlation & $.941^{* *}$ & $.951^{* *}$ & 1 & $.968^{* * *}$ \\
& Sig. (2-tailed) & .000 & .000 & & .000 \\
& $\mathrm{~N}$ & 782 & 782 & 782 & 782 \\
\hline Tax Culture & Pearson Correlation & $.977^{* *}$ & $.953^{* *}$ & $.968^{* * *}$ & 1 \\
& Sig. (2-tailed) & .000 & .000 & .000 & \\
& $\mathrm{~N}$ & 782 & 782 & 782 & 782 \\
\hline
\end{tabular}

**. Correlation is significant at the 0.01 level (2-tailed).

Source: SPSS Output, 2015

Table 2: Coefficients ${ }^{\mathrm{a}}$

\begin{tabular}{|c|c|c|c|c|c|c|c|c|}
\hline & \multirow[t]{2}{*}{ Model } & \multicolumn{2}{|c|}{$\begin{array}{c}\text { Unstandardized } \\
\text { Coefficients }\end{array}$} & \multirow{2}{*}{$\begin{array}{c}\text { Standardized } \\
\text { Coefficients } \\
\text { Beta }\end{array}$} & \multirow[t]{2}{*}{$\mathbf{T}$} & \multirow[t]{2}{*}{ Sig. } & \multirow[t]{2}{*}{$\mathbf{F}$} & \multirow{2}{*}{$\begin{array}{l}\text { Adjusted } \\
\text { R Square }\end{array}$} \\
\hline & & $\bar{B}$ & Std. Error & & & & & \\
\hline \multirow[t]{5}{*}{1} & (Constant) & -.686 & .095 & & -7.223 & .000 & 11445.6 & .978 \\
\hline & Government & .468 & .015 & .535 & 32.098 & .000 & & \\
\hline & Accountability & & & & & & & \\
\hline & Transparency & .152 & .019 & .147 & 8.056 & .000 & & \\
\hline & Public Interest & .341 & .021 & .325 & 16.278 & .000 & & \\
\hline
\end{tabular}

a. Predictors: (Constant), Govt. Accountability, Transparency, Public Interest

b. Dependent Variable: Tax Culture

Source: SPSS Output, 2015

The result from the two tables above was also on effect of Government's accountability, transparency and act in the interest of the public on sustainable tax culture in Nigeria. The Adjusted $R^{2}$ which is goodness of fit (0.978) indicates that over 97.8 percent of the observed changes in sustainable tax culture in Nigeria can be explained by Government's accountability, transparency and action in the interest of the public. The F-statistics of 11445.6 shows a high level of variation in the dependent variables confirming that the overall model had a high predictive power. In a similar vein the T-statistics of the independent variables is positive and significantly affects the dependent variable. It follows, therefore, that government's accountability [tcal $=32.098>\mathrm{t}_{0.05}=1.96$ ], transparency [tcal $=8.056>\mathrm{t}_{0.05}=1.96$ ] and act in the interest of the public $\left[\mathrm{tcal}=16.278>\mathrm{t}_{0.05}=1.96\right.$ ] create a sustainable tax culture in Nigeria.

Table 3 presents the correlational results of the relationship between defined responsibility of government activities, reporting mechanism, system review, reward and sanctions enhance Nigerian tax culture. The results show significant correlations between defined responsibility of government activities [ $\mathrm{rcal}=0.573>\mathrm{t} \mathrm{cri}=0.05]$, reporting mechanism $[\mathrm{rcal}=0.953>\mathrm{t} \mathrm{cri}=0.05]$, system reviews and sanction $[\mathrm{rcal}=0.953>\mathrm{t} \mathrm{cri}=0.05]$ and Nigerian tax culture. 
Table 3: Correlations

\begin{tabular}{|ll|r|r|r|r|}
\hline & $\begin{array}{c}\text { Defined } \\
\text { Resp. }\end{array}$ & $\begin{array}{c}\text { Reporting } \\
\text { Mechanism }\end{array}$ & $\begin{array}{c}\text { System review } \\
\text { and sanction }\end{array}$ & $\begin{array}{c}\text { Nigerian tax } \\
\text { culture }\end{array}$ \\
\hline Defined & Pearson Correlation & 1 & $.761^{* *}$ & $.531^{* * *}$ & $.573^{* * *}$ \\
Responsibility & Sig. (2-tailed) & 782 & .000 & .000 & .000 \\
& $\mathrm{~N}$ & 782 & 782 & 782 \\
\hline Reporting & Pearson Correlation & $.761^{* *}$ & 1 & $.509^{* * *}$ & $.597^{* *}$ \\
Mechanism & Sig. (2-tailed) & .000 & & .000 & .000 \\
& $\mathrm{~N}$ & 782 & 782 & 782 & 782 \\
\hline System review and & Pearson Correlation & $.531^{* *}$ & $.509^{* *}$ & 1 & $.603^{* *}$ \\
sanction & Sig. (2-tailed) & .000 & .000 & & .000 \\
& $\mathrm{~N}$ & 782 & 782 & 782 & 782 \\
\hline Nigerian tax & Pearson Correlation & $.573^{* *}$ & $.597^{* *}$ & $.603^{* *}$ & 1 \\
culture & Sig. (2-tailed) & .000 & .000 & .000 & 782 \\
& $\mathrm{~N}$ & 782 & 782 & 782 & 782 \\
\hline
\end{tabular}

**. Correlation is significant at the 0.01 level (2-tailed).

Table 4: Coefficients ${ }^{\mathrm{a}}$

\begin{tabular}{|c|c|c|c|c|c|c|c|c|}
\hline & \multirow{2}{*}{ Model } & \multicolumn{2}{|c|}{$\begin{array}{c}\text { Unstandardized } \\
\text { Coefficients }\end{array}$} & \multirow{2}{*}{$\begin{array}{c}\begin{array}{c}\text { Standardized } \\
\text { Coefficients }\end{array} \\
\text { Beta }\end{array}$} & \multirow{2}{*}{$\mathbf{T}$} & \multirow{2}{*}{ Sig. } & \multirow{2}{*}{$\mathbf{F}$} & \multirow{2}{*}{$\begin{array}{l}\text { Adjusted } \\
\text { R Square }\end{array}$} \\
\hline & & B & $\begin{array}{l}\text { Std. } \\
\text { Error }\end{array}$ & & & & & \\
\hline \multirow[t]{4}{*}{1} & (Constant) & 2.772 & .462 & & 5.999 & .000 & 245.793 & .485 \\
\hline & $\begin{array}{l}\text { Defined } \\
\text { Responsibility }\end{array}$ & .136 & .036 & .154 & 3.763 & .000 & & \\
\hline & $\begin{array}{l}\text { Reporting } \\
\text { Mechanism }\end{array}$ & .284 & .040 & .289 & 7.178 & .000 & & \\
\hline & $\begin{array}{l}\text { System review } \\
\text { and sanction }\end{array}$ & .370 & .031 & .374 & 12.108 & .000 & & \\
\hline
\end{tabular}

a. Predictors: (Constant), Defined Responsibility, Reporting Mechanism, System review and sanction b. Dependent Variable: Nigerian tax culture

Source: SPSS Output, 2015

The result on table four shows the effect of clear definition of responsibility, adherence to reporting mechanism, and strict system review and sanctions on Nigerian tax culture. The adjusted $\mathrm{R}^{2}$ value of 0.485 or 48.5 percent indicates that about $49 \%$ of the observed changes in the Nigerian tax culture are explained by clear definition of responsibility, adherence to reporting mechanism, and strict system review and sanctions; while overall statistical significance which is measured by the F-statistic $=245.793$ confirms that the model has a high predictive power. The T-statistic value of clear definition of responsibility [tcal $=3.763>\mathrm{t}_{0.05}=1.96$ ], adherence to reporting mechanism [tcal $=7.178>\mathrm{t}_{0.05}=$ 1.96] and strict system review and sanctions [tcal $=12.108>\mathrm{t}_{0.05}=1.96$ ] were all positive and significantly affect the Nigerian tax culture.

Table 5 shows the descriptive statistics of the cross session of tax payers from Edo, Enugu and Bayelsa States. The sample size of the respondents is 782 comprising 256 from Edo State, 299 from Enugu State and 227 from Bayelsa State. This large data set makes it ideal to use Multivariate Analysis of variance. Items 1 to 5 - consequences of government unaccountability were utilized as dependent variables, while States stand as the independent variable. The mean and standard deviation of each item were quite high for all the items within the States. 
Table 5: Descriptive Statistics on the consequences of government unaccountability

\begin{tabular}{|c|c|c|c|c|}
\hline Consequences of government's unaccountability & Group & Mean & Std. Deviation & $\mathbf{N}$ \\
\hline \multirow[t]{4}{*}{ Unfavorable tax culture } & Edo State & 17.9766 & 7.36496 & 256 \\
\hline & Enugu State & 17.8763 & 7.13542 & 299 \\
\hline & Bayelsa State & 17.2819 & 7.08543 & 227 \\
\hline & Total & 17.7366 & 7.19383 & 782 \\
\hline \multirow{4}{*}{$\begin{array}{l}\text { Lackadaisical attitude towards government's socio- } \\
\text { economic policies }\end{array}$} & Edo State & 15.4922 & 6.53017 & 256 \\
\hline & Enugu State & 14.9833 & 6.08246 & 299 \\
\hline & Bayelsa State & 14.5154 & 6.09537 & 227 \\
\hline & Total & 15.0141 & 6.24006 & 782 \\
\hline \multirow[t]{4}{*}{ High level of tax evasion and avoidance } & Edo State & 15.6836 & 6.09641 & 256 \\
\hline & Enugu State & 15.4716 & 5.71543 & 299 \\
\hline & Bayelsa State & 14.8634 & 6.03631 & 227 \\
\hline & Total & 15.3645 & 5.93748 & 782 \\
\hline \multirow[t]{4}{*}{ Loss of government popularity and tax officials } & Edo State & 15.0313 & 6.24963 & 256 \\
\hline & Enugu State & 14.8528 & 5.73214 & 299 \\
\hline & Bayelsa State & 14.5286 & 5.89981 & 227 \\
\hline & Total & 14.8171 & 5.94995 & 782 \\
\hline \multirow[t]{4}{*}{ Loss of trust and confidence in government } & Edo State & 16.7383 & 5.89565 & 256 \\
\hline & Enugu State & 16.5987 & 6.29899 & 299 \\
\hline & Bayelsa State & 16.8502 & 5.31857 & 227 \\
\hline & Total & 16.7174 & 5.88935 & 782 \\
\hline
\end{tabular}

Source: SPSS output, 2015

Table 6 shows that the multivariate tests of significance were conducted using Wilks' Lamda. The Wilks' Lamda value is .966 which is higher than 0.05 . There is a statistical significant difference in the perception of tax payer from the different States on the consequences of government unaccountability. When the results for the dependent variables are considered together $(\mathrm{F}=2.707, \mathrm{p}=.000)$, the magnitude of the variance is of small effect (partial eta squared $=.017$ ). Thus, there are consequences for government unaccountability of tax payers' money.

Table 6: Multivariate Tests ${ }^{\mathrm{c}}$

\begin{tabular}{|ll|r|r|r|r|r|r|}
\hline & Effect & Value & F & Hypothesis df & Error df & \multicolumn{1}{c|}{ Sig. } & $\begin{array}{c}\text { Partial Eta } \\
\text { Squared }\end{array}$ \\
\hline Intercept & Pillai's Trace & .933 & $2167.347^{\mathrm{a}}$ & 5.000 & 775.000 & .000 & .933 \\
& Wilks' Lambda & .067 & $2167.347^{\mathrm{a}}$ & 5.000 & 775.000 & .000 & .933 \\
\hline Group & Pillai's Trace & .034 & 2.707 & 10.000 & 1552.000 & .003 & .017 \\
& Wilks' Lambda & .966 & $2.716^{\mathrm{a}}$ & 10.000 & 1550.000 & .003 & .017 \\
\hline
\end{tabular}

a. Exact statistic

b. The statistic is an upper bound on $\mathrm{F}$ that yields a lower bound on the significance level.

c. Design: Intercept + Group

Source: SPSS output, 2015

\section{Conclusion}

The findings meticulously answered the research questions posed in the course of the work and it was discovered that government's accountability, transparency and act in the interest of the public create a sustainable tax culture in Nigeria. This was somewhat in consonant with Bobek (1997) who specified that taxpayer's attitude towards tax is an 
expression of his belief and judgement on the fairness of the system; and that they are simply motivated by the benefit derivable from the system. It was also corroborated by Alm, Mccelland and Schulze (1992) who added that trust in government affect tax compliance of citizens and increase their tendency to declare taxable revenue more precisely; government can only be trusted when they are accountable, transparent and act in the interest of the public, which goes to show the reason why an unfavorable tax culture is shaped by government breach of trust and high level of corruption among government officials. It was also discovered that government's clear definition of responsibility, adherence to reporting mechanism, and strict system review and sanctions enhance Nigerian tax culture. This reveals that governments should meticulously outline their responsibilities and ensure that mechanisms for checks and balances are put in place; while people-oriented programs carried out by them must be made known to the government and on the ground of mischievousness by any government of officials must be met by sanction. However, where this is not observed, consequences of government's unaccountability to its citizenry abounds; resulting unfavorable tax culture that is characterized by high level of tax evasion and avoidance, lackadaisical attitude towards government's socioeconomic policies and loss of trust and confidence in the government. It is, therefore, recommended that in order to boast the Nigerian tax culture, government should be accountable, transparent and always act in the best interest of the public. Governments must have a defined responsibility and must adhere strictly to their reporting mechanism while reviewing their activities monthly or quarterly and impose sanction on any government officials that are mischievous.

\section{References}

- Abbah, T., Abubakar, A., Abdallah, N. M. and Adebayo, I., (July 24, 2011).Nigeria: EFCC, ICPC under siege. Daily trust Newspaper.

- Achor, A. J. A. (2014). Tax Dispute Resolution in Nigeria: A Storm in a Tea Cup. Journal of Law, Policy and Globalization. 29 (1)147-156.

- Alm, J., G.H. McClelland, K. and Schulze, W. (1992). "Why Do People Pay taxes?", Journal of Public Economics, 48: 21-48.

- Appah, E. and Appiah, K. Z. A. (2010). "Fraud and Development of Sound Financial Institutions in Nigeria", Nigerian Journal for Development Research, 1(1): 49 - 56.

- Bobek, D. D. (1997). How do individuals judge fairness and what effect does it have on their behaviour?(Federal income tax, Theory of planned behaviour). Ann Arbor: UMI.

- Jim-Nwo, U. (May 15, 2014). The role of the fiscal responsibility commission. Business day Newspaper

- Okoh, L. and Ohwoyibo, O. (2010). "Public Accountability: Vehicle for Socio-Economic Development of Nigeria", International Journal of Investment and Finance, 3(1 and 2): 145-149.

- Okoh, L. and Ohwoyibo, O. (2010). "Public Accountability: Vehicle for Socio-Economic Development of Nigeria", International Journal of Investment and Finance, 3(1 and 2): 145-149.

- Olowu, D. (2002). "Accountability and Transparency", in Adamolekun, L. (ed) Public Administration in Africa: Main Issues and Selected Country Studies. Ibadan: Spectrum Books Limited. 139-158

- Olowu, D. (2002). "Accountability and Transparency", in Adamolekun, L. (ed) Public Administration in Africa: Main Issues and Selected Country Studies. Ibadan: Spectrum Books Limited. 139-158

- Onuba, F. (May, 12 2013). Nigerians lack tax culture. The Punch Newspapers

- Roth, J. A., J. T. Scholz, and A. Dryden-Witte, (1989). Taxpayer Compliance Volume 1: An Agenda for Research. Philadelphia, PN: University of Pennsylvania Press.

- Udo, B. (March 3, 2015). Nigerian Corruption Rating, Political, Overblown- Jonathan. Premium times Newspaper. 